\title{
Staphylococcus aureus protein A-antibody-mediated haemagglutination for the analysis of cross-reactivity between phenol-water extracts of Bacteroides fragilis
}

\author{
N. SRINIVASAKUMAR* and R. S. RAO

\begin{abstract}
Department of Microbiology, Jawaharlal Institute of Postgraduate Medical Education and Research, Pondicherry 605 006, India
\end{abstract}

\begin{abstract}
Summary. Passive haemagglutination (PHA) and Staphylococcus aureus protein Aantibody-mediated haemagglutination (SAPA-AMHA) were used to analyse the cross-reactions of rabbit antisera against four stains of Bacteroides fragilis. There was cross-reactivity between all the strains tested but strain-specific reactions were obtained with three strains. Two to 32-fold higher antibody titres were obtained with SAPA-AMHA than with PHA. The antigen concentration required in inhibition assays was up to 32-fold higher for PHA than for SAPA-AMHA. The latter is a simple and superior alternative to PHA for such studies.
\end{abstract}

\section{Introduction}

The antigenic heterogeneity amongst strains of Bacteroides fragilis is similar to that seen in the genus Salmonella (Hofstad, 1977). Depending on the sensitivity of the procedure, various degrees of cross-reactivity have been demonstrated between strains of Bacteriodes by agglutination (Elhag and Tabaqchali, 1978), passive haemagglutination (PHA) (Hofstad, 1977), indirect immunofluorescence (Schwan et al., 1982) and enzyme linked immunosorbent assay (Poxton, 1979).

Staphylococcus aureus protein A-antibodymediated haemagglutination (SAPA-AMHA) (Jagannath et al., 1984) is a more sensitive assay for IgG antibody than PHA and was thus thought to be more suitable for the analysis of cross-reactivity between $B$. fragilis antigens with rabbit immune sera containing predominantly IgG antibodies.

\section{Materials and methods}

\section{Bacteria}

B. fragilis NCTC nos. 9343, 9344, 10581, 10584 and 8560 were kindly supplied by $\mathrm{Dr}$ A. Schwan, University of Uppsala, Uppsala, Sweden. Identification of these strains was confirmed by Gram's stain, aerobic and anaerobic

Received 22 Apr. 1985; accepted 30 July 1985.

* Present address for correspondence: Dr N. Srinivasakumar, 29, Hawthorne Avenue, Buffalo, NY 14223, USA. culture, biochemical tests and ability to grow on bileaesculin agar (Sutter et al., 1980).

\section{Antigen preparation}

Phenol-water extracts (PWE) were prepared as follows. Bacteria were grown anaerobically for $48 \mathrm{~h}$ on Brain Heart Infusion Agar supplemented with sheep blood 5\%, vitamin $\mathrm{K}_{1} 10 \mu \mathrm{g} / \mathrm{ml}$, haemin $5 \mu \mathrm{g} / \mathrm{ml}$ and yeast extract $0.5 \%$ (Sutter et al., 1980). Harvested bacteria were washed three times with cold sterile physiological saline and suspended to a concentration of $200 \mathrm{mg}$ wet weight $/ \mathrm{ml}$. The suspensions were sonicated separately in ice baths for 10-15 min with a 150 watt MSE ultrasonic disintegrator at an amplitude of $12 \mu$. The sonicates were then extracted with aqueous phenol $90 \% \mathrm{w} / \mathrm{v}$ at $65^{\circ} \mathrm{C}$ (Sutherland, 1978) to yield PWE antigens. These were treated with RNAase (Sigma) and DNAase (Sigma) as described by Hofstad and Kristoffersen (1970) and adjusted to a concentration of $1 \mathrm{mg} / \mathrm{ml}$. At the concentrations used in this study, the protein content estimated by the method of Lowry et al. (1951) was negligible in the PWE preparations.

\section{Rabbit antisera}

Antisera were raised separately for each strain in rabbits by injections of formalinised bacteria as described by Elhag et al. (1977).

Preparation of double-aldehyde-stabilised (DAS) red cells

Human group ' $\mathrm{O}$ ' red blood cells were treated with glutaraldehyde, tannic acid and pyruvic aldehyde as described by Jagannath and Sengupta (1983). 


\section{Sensitisation of DAS red cells}

PWE antigens were treated with $0.25 \mathrm{~N} \mathrm{NaOH}$ for $1 \mathrm{~h}$ at $56^{\circ} \mathrm{C}$ and neutralised with $0.25 \mathrm{~N} \mathrm{HCl}$. DAS red cells were washed three times with phosphate buffered saline, $p \mathrm{H} \mathrm{7.2}$ (PBS) and 100- $\mu$ l volumes were suspended in various concentrations of PWE antigens and incubated for $2 \mathrm{~h}$ at $37^{\circ} \mathrm{C}$ and then overnight at $4^{\circ} \mathrm{C}$. The sensitised red cells were then washed twice with PBS, once with PBS containing $0.1 \%$ bovine serum albumin (diluent) and resuspended to $1 \%$ in the latter. The optimal sensitising dose was defined as the lowest concentration of antigen that gave the maximum haemagglutination titre with homologous rabbit antiserum.

\section{Passive haemagglutination ( $\mathrm{PHA}$ )}

Antibody assay. PHA titration was performed in Ubottom microtitration plates. After absorption with unsensitised DAS cells to remove heterophile antibodies, antisera were serially double diluted and $25 \mu \mathrm{l}$ of sensitised red cells were added to $25-\mu$ l volumes of diluted antisera. The plate was shaken for $2 \mathrm{~min}$ and incubated at room temperature for $2 \mathrm{~h}$. PHA patterns were recorded as described by Stavitsky (1954).

Inhibition of PHA (Hofstad, 1977). PWE antigens $(25 \mu \mathrm{l})$ were serially double diluted from wells 1 to 11 in microtitration plates. The first well contained $12.5 \mu \mathrm{g}$ and the eleventh well $0.012 \mu \mathrm{g}$ of the antigen. Antiserum $(25 \mu \mathrm{l})$, containing 8 haemagglutinating units, was then added to wells $2-12$. Wells 1 and 12 were controls. The plate was shaken for $2 \mathrm{~min}$ and incubated at room temperature for $1 \mathrm{~h}$ before addition of $25 \mu \mathrm{l}$ of sensitised red-cells suspensions to each well. Haemagglutination patterns of $\mathrm{i}+$ or less were taken to indicate inhibition of PHA.

S. aureus protein A-antibody-mediated haemagglutination ( $S A P A-A M H A)$

$S$. aureus cells bearing protein A (SAPA) were prepared from Cowan I cells grown in Casein hydrolysate-CystineYeast extract broth (Arvidson et al., 1971) and stabilised with formalin and heat as described by Kessler (1975). Before titration, antisera were absorbed with unsensitised DAS red cells and formalin-fixed protein A-negative $S$. aureus strain Wood 46 cells (Jagannath et al., 1984).

Antibody assay. The microtitration protocol described by Jagannath et al. (1984) was followed. Briefly, to 25- $\mu$ l volumes of serially double diluted antisera in microtitration plates an equal volume of an optimal concentration (determined by a preliminary titration) of SAPA cells (usually $0.2 \% \mathrm{w} / \mathrm{v}$ ) was added. The plates were then agitated gently on a horizontal shaker for $30 \mathrm{~min}$ before the addition of sensitised red cells as for PHA. Controls included sensitised red cells mixed with SAPA cells in the absence of serum. The co-haemagglutination (CHA) patterns, which are similar to PHA patterns, were scored as for PHA.

Inhibition of CHA (Jagannath et al., 1984). Antibody- coated SAPA cells were prepared by mixing equal volumes of SAPA cells at the optimal concentration $(0.2 \% \mathrm{w} / \mathrm{v})$ and $4 \mathrm{CHA}$ units of antiserum (one CHA unit is the highest dilution of antiserum giving a $3+$ reaction in SAPA-AMHA) which were then incubated at $37^{\circ} \mathrm{C}$ for $1 \mathrm{~h}$. After washing three times in PBS, the cells were suspended to the original concentration in diluent.

The assay was conducted by adding $25 \mu \mathrm{l}$ of antibodycoated SAPA cells to $25-\mu$ l volumes of serially double diluted PWE antigens in microtitration wells. The plates were shaken for $2 \mathrm{~min}$, incubated at room temperature for $1 \mathrm{~h}$ and $25 \mu \mathrm{l}$ of sensitised red cells were added to each well. As controls, SAPA cells coated with normal rabbit serum were titrated against sensitised and unsensitised DAS red cells, and SAPA cells coated with immune rabbit serum were titrated against unsensitised DAS red cells. A CHA reaction of $1+$ or less was taken to indicate inhibition of CHA.

\section{Cross-absorption studies}

Antisera were absorbed with equal volumes of appropriately sensitised packed DAS red cells before assay by PHA and SAPA-AMHA at starting dilutions of 1 in 20 and 1 in 40 respectively. For example (table III) antiserum to NCTC 9343 was absorbed with NCTC 10584 PWE antigen-sensitised DAS red cells and then titrated by PHA and SAPA-AMHA against PWE antigen-sensitized DAS red cells of the four stains of $B$. fragilis.

\section{Results}

Table I shows the results of cross-titration of the four PWE antigens against homologous and heterologous rabbit antisera by PHA and SAPA-AMHA. Strain NCTC 8560 was not included in the study because its PWE antigen bound poorly to DAS red cells.

With PHA and SAPA-AMHA, two-way crossreactions were seen between strains NCTC 9343 and NCTC 10584 and between strains NCTC 9344 and NCTC 10581. However, by SAPA-AMHA alone, a significant degree of cross-reactivity with NCTC 9344 and NCTC 10581 could be demonstrated in rabbit anti-NCTC 9343 serum, and with NCTC 10581 in rabbit anti-NCTC 10584 serum.

In inhibition experiments (table II), the results of PHA and SAPA-AMHA appeared to be identical in that PWE antigens inhibited homologous antigen-antibody systems. No inhibition of heterologous systems was evident with PWE antigens of NCTC 9344 and NCTC 10581 at the concentrations used. PWE antigen from NCTC 9343 inhibited the reaction of PWE antigen from NCTC 10584sensitised DAS red cells with rabbit anti-NCTC 10584, and similarly PWE antigen of NCTC 10584 was found to inhibit the reaction of PWE antigen of 
Table I. Antibody titres to PWE antigens of $B$. fragilis in homologous and heterologous rabbit antisera tested by PHA and SAPA-AMHA

\begin{tabular}{|c|c|c|c|c|c|c|c|c|c|}
\hline & & \multicolumn{8}{|c|}{ Titre with antisera to NCTC strains } \\
\hline \multirow{2}{*}{\multicolumn{2}{|c|}{$\begin{array}{l}\text { PWE antigen } \\
\text { derived from } \\
\text { strain }\end{array}$}} & \multicolumn{2}{|c|}{9343} & \multicolumn{2}{|c|}{10581} & \multicolumn{2}{|c|}{9344} & \multicolumn{2}{|c|}{10584} \\
\hline & & $\mathbf{P}$ & $\mathbf{S}$ & $\mathbf{P}$ & $\mathrm{S}$ & $\mathbf{P}$ & $\mathbf{S}$ & $\mathbf{P}$ & $\mathbf{S}$ \\
\hline NCTC & 9343 & 160 & 2560 & $<20$ & 20 & $<20$ & 40 & 80 & 5120 \\
\hline NCTC & 10581 & 20 & 160 & 320 & 5120 & 80 & 2560 & 20 & 160 \\
\hline NCTC & 9344 & 20 & 80 & 160 & 640 & 160 & 5120 & 20 & 20 \\
\hline NCTC & 10584 & 160 & 1280 & 20 & $<20$ & $<20$ & $<20$ & 80 & 1280 \\
\hline
\end{tabular}

P = PHA $;$ S = SAPA-AMHA.

Table II. Degree of cross-reactivity between strains of $B$. fragilis evaluated by inhibition of PHA (IP) and inhibition of SAPA-AMHA (IS)*

\begin{tabular}{|c|c|c|c|c|c|}
\hline \multirow{3}{*}{$\begin{array}{l}\text { PWE antigen } \\
\text { used for inhibition }\end{array}$} & \multicolumn{3}{|c|}{ System } & \multirow{2}{*}{\multicolumn{2}{|c|}{$\begin{array}{l}\text { Minimum inhibitory } \\
\text { concentration }(\mu \mathrm{g})\end{array}$}} \\
\hline & \multirow{2}{*}{$\begin{array}{l}\text { PWE antigen } \\
\text { used for } \\
\text { sensitisation }\end{array}$} & \multirow{2}{*}{ vs } & \multirow{2}{*}{$\begin{array}{l}\text { Rabbit anti- } \\
\text { serum raised } \\
\text { against strain }\end{array}$} & & \\
\hline & & & & IP & IS \\
\hline NCTC 9343 & NCTC 9343 & & NCTC 9343 & $1 \cdot 56$ & 0.39 \\
\hline NCTC 9343 & NCTC 10584 & & NCTC 10584 & 0.78 & 0.024 \\
\hline NCTC $10584^{\circ}$ & NCTC 10584 & & NCTC 10584 & 0.39 & 0.048 \\
\hline NCTC 10584 & NCTC 9343 & & NCTC 9343 & $1 \cdot 56$ & 0.39 \\
\hline NCTC 9344 & NCTC 9344 & & NCTC 9344 & $6 \cdot 35$ & 0.78 \\
\hline NCTC 10581 & NCTC 10581 & & NCTC 10581 & $3 \cdot 13$ & $3 \cdot 13$ \\
\hline
\end{tabular}

* Only combinations in which inhibition was observed are shown.

NCTC 9343-sensitised DAS red cells with rabbit anti-NCTC 9343.

Antigen concentrations in the range 0.024 $0.78 \mu \mathrm{g}$ were sufficient to inhibit the reaction between antibody-coated SAPA cells and homologous antigen-sensitised red cells (inhibition of CHA), while antigen concentrations of 0.39 $6.25 \mu \mathrm{g}$ were required for inhibition of PHA (table II). However, for PWE antigen of NCTC 10581 alone, inhibition of homologous system occured at similar concentrations in both PHA and SAPAAMHA.

After cross-absorption (table III), antisera generally retained the ability to react with homologous antigens except with rabbit anti-NCTC 10584, from which antibodies to homologous antigen were completely removed by absorption with DAS red cells sensitised with antigen from NCTC 9343.
Table III. Effect of cross-absorption of heterologous rabbit antisera on the antibody titres to PWE antigens of B. fragilis tested by PHA(P) and SAPA-AMHA (S)*

\begin{tabular}{|c|c|c|c|c|c|c|c|c|}
\hline \multirow{3}{*}{$\begin{array}{l}\text { PWE antigen used } \\
\text { for sensitisation }\end{array}$} & \multicolumn{8}{|c|}{ Titre with antisera to NCTC strains $\dagger$} \\
\hline & \multicolumn{2}{|c|}{$9343^{\mathrm{a}}$} & \multicolumn{2}{|c|}{$10581^{\mathrm{b}}$} & \multicolumn{2}{|c|}{$9344^{\mathrm{c}}$} & \multicolumn{2}{|c|}{$10584^{\mathrm{d}}$} \\
\hline & $\mathbf{P}$ & $S$ & $\mathbf{P}$ & $\mathrm{S}$ & $\mathbf{P}$ & $S$ & $\mathrm{P}$ & $\mathrm{S}$ \\
\hline NCTC 9343 & - & 40 & nt & - & $\mathrm{nt}$ & - & - & - \\
\hline NCTC 10581 & $\mathrm{nt}$ & - & 80 & 320 & - & - & $\mathrm{nt}$ & - \\
\hline NCTC 9344 & $\mathrm{nt}$ & - & - & - & 80 & 320 & $\mathrm{nt}$ & - \\
\hline NCTC 10584 & - & - & $\mathrm{nt}$ & - & nt & - & - & - \\
\hline
\end{tabular}


Again, with SAPA-AMHA alone, a minor degree of reactivity to homologous antigen-sensitised red cells was demonstrable in rabbit anti-NCTC 9343 serum absorbed with red cells sensitised with antigen from NCTC 10584.

\section{Discussion}

Previous studies with agglutination (Elhag and Tabaqchali, 1978) and immunofluorescence (Schwan, 1981) suggested that a pool of $B$. fragilis strains consisting of NCTC nos. 9343, 9344, 10581, 10584 and 8560 would be suitable for serodiagnosis of infections caused by this organism. After appropriate modification with $\mathrm{NaOH}$ or heat, PWE antigens have been shown to bind to red blood cells (Neter, 1956). Thus, in this study, we have analysed the PWE antigens of these $B$. fragilis strains for cross-reactivity by PHA and SAPA-AMHA. Our results indicate than an antigen or antigenic determinant is common to strains which are thought to be representative of $B$. fragilis (Kasper et al., 1983; Linko-Kettunen et al., 1984). While strain-specific determinants have been demonstrated by crossabsorption experiments, PWE antigens of strains NCTC 9343 and NCTC 10584 appear almost identical.

These results are similar to those of Hofstad (1977), who provided evidence for cross-reacting and strain-specific determinants in PWE antigens of B. fragilis strains by PHA. While confirming the earlier observations (Elhag and Tabaqchali, 1978; Schwan et al., 1982) that there is a significant degree of cross-reactivity between $B$. fragilis strains NCTC 10581 and NCTC 9344, it was possible in this study to demonstrate greater levels of cross-reactivity amongst the strains.

PWE antigens are likely to contain both lipopolysaccharide (LPS) and capsular polysaccharide (CP). A recent study with monoclonal antibodies (LinkoKettunen et al., 1984) confirmed that $B$. fragilis LPS is responsible for species specificity while CP appears to confer strain specificity (Kasper et al., 1983). Because we did not attempt to increase the CP content by passage through mouse spleen (Kasper et al., 1983), the greater level of crossreactivity observed in this study could be due to

\section{REFERENCES}

Arvidson S, Holme T, Wadström T 1971 Influence of cultivation conditions on the production of extracellular proteins by Staphylococcus aureus. Acta Pathologica Microbiologica Scandinavica Section B 79:399-405. differences in the antigens or in techniques used for analysis or both.

A comparison of PHA and SAPA-AMHA (table I) confirmed the greater sensitivity of SAPAAMHA. In agreement with the previous observations (Jagannath et al., 1984) SAPA-AMHA gave titres two to 32-fold greater than PHA. This range of enhancement has been attributed to the presence of different levels of IgG class antibodies in the antisera and to the Fc binding activity of protein Abearing $S$. aureus (Jagannath et al., 1984). The increased sensitivity of SAPA-AMHA made possible the demonstration of minor cross-reactions between the various strains in this study.

Inhibition experiments with SAPA-AMHA (table II) also proved to be more sensitive than PHA. This was ascribed to the smaller number of antibody molecules involved in the $\mathrm{CHA}$ reaction and the correspondingly smaller quantities of antigen necessary for inhibition (Jagannath et al., 1984). It is apparent that a decrease in the concentration of antibodies used to coat SAPA cells will enhance the sensitivity of the inhibition assay. However, the optimal dilution of antiserum for conducting the assay must be determined by a preliminary titration. Although a detailed study of antibody concentrations in the inhibition assay was not undertaken, a dilution of antiserum containing 4 CHA units appears to be suitable for most assays because at this dilution there was good correlation between inhibition and cross-absorption experiments (table III).

The results of this study do not indicate the combination of antigens necessary for serodiagnosis with PWE antigens. This will have to be determined with PWE antigens derived from a larger number of $\boldsymbol{B}$. fragilis strains. Moreover, defined antigen preparations, such as purified LPS (devoid of CP), will have to be evaluated in this system.

However, SAPA-AMHA appears to offer some advantages for the study of cross-reactivities between antigen preparations suitable for sensitisation of red blood cells.

We thank Dr C. Jagannath, NICD, Bangalore, India, for helpful advice and suggestions.

Elhag K M, Bettelheim K A, Tabaqchali S 1977 Serological studies of Bacteroides fragilis. Journal of Hygiene 79:233241.

Elhag K M, Tabaqchali S 1978 A study of the surface and somatic antigens of Bacteroides fragilis. Journal of Hygiene 80:439-449. 
Hofstad T, Kristoffersen T 1970 Chemical characteristics of endotoxin from Bacteroides fragilis NCTC 9343. Journal of General Microbiology 61:15-19.

Hofstad T 1977 Cross-reactivity of Bacteroides fragilis O antigens. Acta Pathologica Microbiologica Scandinavica Section B 85:9-13.

Jagannath C, Sengupta D N 1983 Serology of tuberculosis. I. Standardization of passive haemagglutination test for the measurement of antibodies to Mycobacterium tuberculosis. Tubercle 64:193-200.

Jagannath C, Sengupta D N, Kasinathan S 1984 Staphylococcus aureus protein $\mathrm{A}$ antibody-mediated haemagglutination assay. A study on the interaction between protein A-bound specific antibodies and red-cell-bound specific antigens. International Archives of Allergy and Applied Immunology 73:296-302.

Kasper D L, Weintraub A, Lindberg A A, Lönngren J 1983 Capsular polysaccharides and lipopolysaccharides from two Bacteroides fragilis reference strains: Chemical and immunochemical characterization. Journal of Bacteriology 153:991-997.

Kessler S W 1975 Rapid isolation of antigens from cells with a Staphylococcal protein A-antibody adsorbent: Parameters of the interaction of antibody-antigen complexes with protein A. Journal of Immunology 115:1617-1624.

Linko-Kettunen L, et al. 1984 Monoclonal antibodies to Bacteroides fragilis lipopolysaccharide. Journal of Clinical Microbiology 20:519-524.
Lowry O H, Rosebrough N J, Farr A L, Randall R J 1951 Protein measurement with folin phenol reagent. Journal of Biological Chemistry 193:265-275.

Neter E 1956 Bacterial hemagglutination and hemolysis. Bacteriological Reviews 20:166-188.

Poxton I R 1979 Serological identification of Bacteroides species by an enzyme-linked immunosorbent assay. Journal of Clinical Pathology 32:294-298.

Schwan A 1981 IgG antibodies against anaerobic bacteria in blood donor sera. Journal of Clinical Pathology 34:416-419.

Schwan A, Danielsson D, Forsum U 1982 Demonstration of heat-labile antigen(s) of Bacteroides fragilis associated with nonhomogenous immunofluorescent staining. Acta Pathologica Microbiologica Immunologica Scandinavica Section B 90:13-19.

Stavitsky A B 1954 Micromethods for the study of proteins and antibodies. I. Procedure and general applications of hemagglutination and hemagglutination-inhibition reactions with tannic acid and protein-treated red blood cells. Journal of Immunology 72:360-367.

Sutherland I W 1978 Separation and purification of bacterial antigens. In: Weir D M, Handbook of experimental immunology 3rd edn. Blackwell Scientific Publications, Oxford. pp 2.1-2.17.

Sutter V L, Citron D M, Finegold S M 1980 Wadsworth anaerobic bacteriology manual, 3rd edn. The CV Mosby Company, St Louis. 